Era, além de um centro de ensino superior, uma escola de pesquizas, que, embora de duração ephemera, deixou bem documentada sua existencia com os novos especialistas que creou e o gosto pelos estudos de Parasitologia que incutiu nos que por ella passaram.

Em collaboração com Arthur Neiva, Cesar Pinto, Paulo Artigas, etc., fundou, em 1926, um orgão de publicações de seu Laboratorio, o Boletim Biologico, revista talvez unica no genero em todo mundo, pois, desprezando proventos de qualquer especie, não acceita assignaturas nem annuncios, sendo distribuida graciosamente aos interessados e centros scientificos de todo o mundo, mantendo-se á custa das contribuições dos seus redactores e de um grupo de cultores ou admiradores da Sciencia, que dão assim raro exemplo do modo pelo qual deve esta ser encarada.

Perto de 70 trabalhos publicados no seu Laboratorio no curto lapso de tempo que medeiou entre sua posse em Março de 1926 e Dezembro de 1928, attestam a fecundidade intellectual do grupo de escól que formára e chefiava.

Como ultima consagração de seus meritos scientificos, recebeu Travassos, cujo alto valor e alta competencia são talvez melhor aquilatados no extrangeiro do do que em nossa Patria, um convite do Instituto de Molestias Tropicaes de Hamburgo (Institut f. Schiffs. u. Tropenkrankheiten) para pesquizar e dar um curso de Helminthologia nessa celebre instituição, encontrando-se em Hamburgo desde o principio do anno corrente.

Dedicando á Sciencia amor entranhado, trabalhador infatigavel, pesquizador de competencia indiscutivel, organisador, formador de élites, Travassos, simples no trato, affectuoso e sensivel, occupará um dia na Sciencia Nacional o logar que por todos os titulos já conquistou.

Vivo Oswaldo Cruz, olharia com orgulho a sua criação e agradeceria ao discipulo os louros que colheu para o MESTRE.

\title{
Prof. Franklin de Moura Campos
}

Tomou posse, não ha muito, da Cadeira de Physiologia e Chimica Physiologica desta Faculdade, o dr. Franklin de Moura Campos.

Moço de grande capacidade de trabalho que é, conseguiu após brilhante concurso o supremo posto do magisterio superior, a sua mais legitima aspiração.

Franklin é o paradigma da nova geração que ora surge no Brasil, propugnador das mais avançadas theorias da Physiologia Moderna, terá pelo seu talento varonil, expondo conviç̧ões baseadas n'um raciocinio irreprehensivel, e trabalhando com toda perseverança de sua inecedivel dedicação, na nossa Faculdade, na cadeira que dirige, o papel de Moraes do Valle na Cathedra de Chimica da Faculdade de Medicina do Rio de Janeiro.

Substituindo o prof. Cantidio de Moura Campos, est'outra intelligencia fecunda a serviço de integro caracter, o fará com vantagens não pelo brilhantismo das exposições mas pela sua devoção de moço emprehendendor.

L. B. 